\title{
Ageing and platelet $\alpha_{2}$-adrenoceptors
}

Studies on the relationship between ageing and platelet $\alpha_{2}$-adrenoceptor number and affinity have yielded conflicting results. In view of the important link between adrenoceptors and platelet aggregation it seems necessary to ascertain if there is a change in the receptor with ageing. We report results obtained by measuring platelet $\alpha_{2}$-adrenoceptor binding site number and affinity using $\left[{ }^{3} \mathrm{H}\right]$-rauwolscine, which is a selective $\alpha_{2}-$ adrenoceptor antagonist and the ligand of choice for these receptors on human platelets (Cheung et al., 1982).

Thirty-five healthy subjects, on no medication and aged 22-82 years, were selected. After 10$20 \mathrm{~min}$ rest, $30 \mathrm{ml}$ blood was drawn from an antecubital vein into lithium heparin tubes (plastic). The blood was centrifuged at $200 \mathrm{~g}$ for $10 \mathrm{~min}$ and platelet-rich plasma was removed and placed in Sorvall tubes. An equal volume of isotonic buffer (Tris-EDTA-NaCl pH 7.4) was mixed with the remaining blood and the tubes centrifuged again for $10 \mathrm{~min}$ at $200 \mathrm{~g}$. The supernatant was removed and added to the plateletrich plasma and the mixture was centrifuged at $30,000 \mathrm{~g}$ for $20 \mathrm{~min}$ at $4^{\circ} \mathrm{C}$. Pellets containing platelets were reconstituted in $11 \mathrm{ml}$ buffer (Tris-EDTA-NaCl) and used immediately in the binding assays: $500 \mu$ l of the solution was used for protein assay, the total protein content being estimated by the Lowry method. Aliquots $(800$ $\mu l)$ of platelet suspension were incubated with various concentrations of $\left[{ }^{3} \mathrm{H}\right]$-rauwolscine ranging from $0.625 \mathrm{nM}$ to $20 \mathrm{nM}$. Incubations were in a total volume of $1 \mathrm{ml}$ at $37^{\circ} \mathrm{C}$ for $30 \mathrm{~min}$.

Ice-cold buffer $(2 \mathrm{ml})$ was added to each tube and the contents filtered through glass-fibre filters (Whatman GF/C $2.5 \mathrm{~cm}$ ) which were washed under low vacuum with a further $2 \times 2 \mathrm{ml}$ of buffer on a multiporal manifold (Millipore). The vacuum-dried filters were counted for radioactivity in scintillation vials containing $5 \mathrm{ml}$ of liquiscint at $44 \%$ counting efficiency, using a Searle Delta 300 liquid scintillation counter. Non-specific binding was estimated by simultaneously carrying aliquots of platelet suspension through the above procedure in the presence of $10^{-4} \mathrm{M}$ phentolamine. The specific binding was obtained by subtracting non-specific binding from the total binding. Specific binding was $50 \%$ of total binding with [ $\left.{ }^{3} \mathrm{H}\right]-$ rauwolscine at $20 \mathrm{nM}$ and $64 \%$ of total binding at $0.625 \mathrm{nM}$. The data were analysed by Scatchard plot. The maximum number of binding sites for $\left[{ }^{3} \mathrm{H}\right]$-rauwolscine was $85.3 \mathrm{fmol} \mathrm{mg}^{-1}$ protein, ranging from 126.5 to $30.26 \mathrm{fmol} \mathrm{mg}^{-1}$ and the binding affinity for $\left[{ }^{3} \mathrm{H}\right]$-rauwolscine $\left(K_{\mathrm{D}}\right)$ was $3.6 \mathrm{nM}$, ranging from $7.7 \mathrm{nM}$ to $1.6 \mathrm{nM}$. Neither binding capacity nor affinity showed a significant correlation with age (Figure 1).

The relationship between ageing and platelet $\alpha_{2}$-adrenoceptor binding has been studied using a variety of ligands. Brodde and colleagues (1982), using [ $\left.{ }^{3} \mathrm{H}\right]$-yohimbine, in 36 subjects varying in age from 14 to 76 years, showed a significant negative correlation $(r=0.666, P<$ 0.001 ) between the number of receptors and age. Neither Motulsky \& colleagues (1983) nor Jones and coworkers (1983), using $\left[{ }^{3} \mathrm{H}\right]$ yohimbine, found a change in affinity or receptor number with advancing years. Elliott and colleagues (1982) found no significant difference

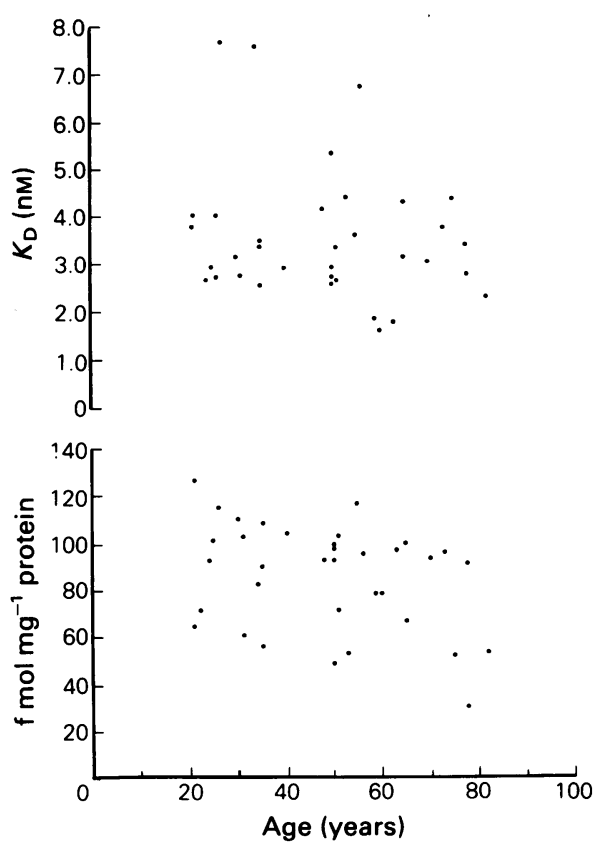

Figure 1 Relationship of age to specific binding of $\left[{ }^{3} \mathrm{H}\right]$-rauwolscine to platelet $\alpha_{2}$-adrenoceptors $(r=$ $0.30, P>0.05)$ and with the dissociation constant, $K_{\mathrm{D}}$, for $\left[{ }^{3} \mathrm{H}\right]$-rauwolscine $(r=0.19, P>0.05)$. 
with age in the binding capacity of $\left[{ }^{3} \mathrm{H}\right]$-dihydroergocryptine, but they did observe a significant negative correlation $(P<0.05)$ between binding affinity and age. On the contrary, Yokoyama and colleagues (1984) showed a significant positive correlation between the binding capacity and age but no change in affinity, with $\left[{ }^{3} \mathrm{H}\right]-$ dihydroergocryptine as ligand.

The diversity of ligands used may contribute to these conflicting results as may differences in platelet preparation and subject gender. The age-related decrease in maximum number of $\alpha_{2}$-adrenoceptor binding sites was observed in platelet membranes rather than intact platelets. The small change in binding affinity described by Elliott et al. (1982) was in intact platelets taken only from men. Our results failed to show a significant correlation with age for either the binding capacity or affinity of $\alpha_{2}$-adrenoceptors on intact human platelets using the highly specific

\section{References}

Brodde, O. E., Anlauf, M., Graben, N. \& Bock, K. D. (1982). Age dependant decrease of alpha 2 adrenergic receptor number in human platelets. Eur. J. Pharmac., 81, 345-347.

Cheung, Y.-D., Barnett, D. B. \& Nahorski, S. R. (1982). $\left[{ }^{3} \mathrm{H}\right]$-rauwolscine and $\left[{ }^{3} \mathrm{H}\right]$-yohimbine binding to rat cerebral and human platelet membranes: possible heterogeneity of alpha ${ }_{2}$ adrenoceptors. Eur. J. Pharmac., 84, 79-85.

Elliott, J. M. \& Grahame-Smith, D. G. (1982). The binding characteristics of $\left[{ }^{3} \mathrm{H}\right]$-dihydroergocryptine on intact human platelets. Br. J. Pharmac., 76, 121-130. $\alpha_{2}$-adrenoceptor antagonist $\left[{ }^{3} \mathrm{H}\right]$-rauwolscine as ligand.

This study will not settle the question of whether or not there is an age related alteration in $\alpha_{2-}$ adrenoceptors but does serve to emphasise the difficulties inherent in comparing ligand binding data measured under different circumstances. The true significance can only be judged by comparing relevant pharmacodynamic data with the binding of one or more ligands.

\section{BUCKLEY, D. CURTIN, T. WALSH \& K. O'MALLEY}

Departments of Physiology, Ophthalmology and Clinical Pharmacology, Royal College of Surgeons in Ireland, Dublin 2, Eire

Received 5 June 1985, accepted 7 December 1985

Jones, S., Bylund, D., Rieser, C., Shekim, W. \& Byer, J. (1983). Alpha 2 adrenergic receptor binding in human platelets: alterations during the menstrual cycle. Clin. Pharmac. Ther., 34, 90-96.

Motulsky, H. J., O'Connor, D. T. \& Insel, P. A. (1983). Platelet alpha $a_{2}$ adrenergic receptors in treated and untreated essential hypertension. Clin. Sci., 64, 265-272.

Yokoyama, M., Kusui, A., Sakamoto, S. \& Fukuzaki, H. (1984). Age associated increments in human platelet alpha adrenoceptor capacity. Possible mechanism for platelet hyperactivity to epinephrine in ageing man. Thrombosis Research, 34, 287-295. 